\title{
Immunosuppressive mechanisms for stem cell transplant survival in spinal cord injury
}

\author{
*Joseph P. Antonios, PhD, ${ }^{1}$ Ghassan J. Farah, BS, ${ }^{2}$ Daniel R. Cleary, MD, PhD, ${ }^{2}$ \\ Joel R. Martin, MD, ${ }^{2}$ Joseph D. Ciacci, MD, ${ }^{2}$ and Martin H. Pham, MD ${ }^{2}$ \\ 'David Geffen School of Medicine, University of California, Los Angeles, Los Angeles; and 'Department of Neurosurgery, \\ University of California San Diego School of Medicine, San Diego, California
}

\begin{abstract}
Spinal cord injury $(\mathrm{SCl})$ has been associated with a dismal prognosis-recovery is not expected, and the most standard interventions have been temporizing measures that do little to mitigate the extent of damage. While advances in surgical and medical techniques have certainly improved this outlook, limitations in functional recovery continue to impede clinically significant improvements. These limitations are dependent on evolving immunological mechanisms that shape the cellular environment at the site of SCl. In this review, we examine these mechanisms, identify relevant cellular components, and discuss emerging treatments in stem cell grafts and adjuvant immunosuppressants that target these pathways. As the field advances, we expect that stem cell grafts and these adjuvant treatments will significantly shift therapeutic approaches to acute $\mathrm{SCl}$ with the potential for more promising outcomes.
\end{abstract}

https://thejns.org/doi/abs/10.3171/2018.12.FOCUS18589

KEYWORDS spinal cord injury; stem cell grafts; immunosuppressants; glial scar

$\mathrm{T}$ HERE has been limited progress in developing reliable therapeutic interventions for spinal cord injury (SCI) ${ }^{5,6,40,43}$ Currently, treatments rely on stabilization and decompression of the spinal cord to restore mechanical homeostasis immediately following injury and controlling secondary complications. ${ }^{8,22}$ While our understanding of the factors that modulate neuronal plasticity and regeneration have improved over the past several decades, these advances have been limited by differences in responses across preclinical animal models, variations in injury mechanics and severities, and heterogeneity in responses observed following current interventions..$^{23,28}$ It is thought that the outcome of SCIs can be addressed through neuroprotection, plasticity, or axonal regeneration..$^{10}$

Because SCIs increase in size after initial trauma or injury, additional functional deficits subsequently develop. Plasticity and neuroprotective treatments may have a potential role in preventing further functional loss in this set- ting. Relevant to our discussion is the concept of axonal regeneration. Significant advances in recreating the complex connections underlying the central nervous system (CNS) following SCI provide a potential therapeutic approach with numerous benefits. In this review, we will examine the immunological mechanisms dictating scar formation following SCI and prospective therapeutic interventions currently being evaluated for use in patients.

\section{Immunological Response in CNS Injury}

Although the peripheral nervous system has a robust system for regeneration and healing following injury, the CNS is thought to be more limited. The CNS was once thought to be an immune-privileged site due to protective barriers; however, it is now known that immune cells are recruited to sites of injury to mediate scar formation and tissue recovery. ${ }^{6}$

ABBREVIATIONS CNS = central nervous system; epSPC = ependymal stem/progenitor cell; FKBP = FK506 binding protein; hESC = human embryonic stem cell; hSSC = human fetal spinal cord stem cell; iNOS = inducible nitric oxide synthase; iPSC = induced pluripotent stem cell; iPSC-NPC = iPSC-derived NPC; MSC = mesenchymal stem cell; NPC = neural precursor cell; OPC = oligodendrocyte progenitor cell; SCI = spinal cord injury; SKP-SC = skin-derived precursor Schwann cell; TNF- $\alpha=$ tumor necrosis factor $\alpha$.

SUBMITTED October 30, 2018. ACCEPTED December 17, 2018.

INCLUDE WHEN CITING DOI: 10.3171/2018.12.FOCUS18589.

* J.P.A. and G.J.F. contributed equally to this work. 
The importance of the immune system in mediating tissue recovery following CNS injury cannot be understated. The primary response to injury is mediated by neutrophils, the most abundant immune cells in the body. Myeloperoxidase, released by these neutrophils, is a peroxidase enzyme within neutrophilic granules that serves to damage host tissue via generation of highly reactive oxygen species. ${ }^{24}$ Studies have shown that inhibition of neutrophils alone at the site of SCI helps with recovery. ${ }^{36,58}$ Within 72 hours of injury, ependymal stem/progenitor cells (epSPCs), which are adult multipotent stem cells that differentiate into both neural and glial cells, are activated. These cells then migrate from the spinal central canal to the site of injury. A majority of epSCPs then differentiate into astrocytes, and a small portion differentiate into myelin-producing oligodendrocytes. ${ }^{1,7}$

Astrocytes recruit macrophages, which then restrict axonal growth, mediate the inflammatory response, and limit the extent of SCI..$^{14,39}$ There is a preponderance of inhibitory molecules released by astrocytes within the forming glial scar. One of these, MCP-1, promotes recruitment of M1 proinflammatory macrophages directly to the site of injury via CCR 2 receptors. These macrophages, acting via release of tumor necrosis factor $\alpha$ (TNF- $\alpha$ ) and inducible nitric oxide synthase (iNOS), are associated with inhibiting neuronal axon growth in the spinal cord ${ }^{41}$ Specifically, TNF- $\alpha$ is a cytokine that increases local concentrations of caspases, resulting in cell apoptosis. Further, iNOS promotes apoptosis of damaged neurons. While this may be beneficial acutely, it results in apoptosis of healthy neurons and inhibition of regrowth and regeneration of axonal connections over a chronic period. ${ }^{47}$

These intrinsic immunological mechanisms are useful in limiting the extent of injury acutely and preventing further damage to the CNS. However, their utility quickly becomes detrimental to neurological recovery following this initial phase-these same factors prevent formation of new neuronal growth, axonal regeneration, and the formation of functional connections in the CNS. As studies have further elucidated these mechanisms, new avenues for therapeutic intervention through the inhibition and modulation of these immunological responses have become paramount.

Chondroitinase $\mathrm{ABC}$ is a bacterial enzyme developed to digest chondroitin sulfate proteoglycans by catalyzing removal of associated sulfate-glycosaminoglycan chains. ${ }^{2}$ This promotes M2 macrophage phenotype at the site of SCI. ${ }^{2}$ Other therapies have targeted TNF- $\alpha$ directly. Epigallocatechin gallate lowers TNF- $\alpha$ levels, resulting in decreased neuronal death and promoting repair mechanisms. ${ }^{21}$ TNF- $\alpha$ antagonists such as etanercept promote stem cell viability and increase functional recovery. ${ }^{55,57}$

\section{Developments in Stem Cell Transplantation}

Over the past decade, a considerable body of evidence has shown the potential efficacy of using stem cell grafts for promoting functional recovery following SCI. Human embryonic stem cells (hESCs), derived from the inner cell mass of preimplantation blastocysts, are able to differentiate into neuronal and glial cells. ${ }^{29}$ Human ESC-derived ol- igodendrocyte progenitor cells (OPCs) can be transplanted into SCI models and clearly demonstrate clinical recovery of neurological function. ${ }^{3,20}$ Furthermore, these cells successfully differentiate into mature oligodendrocytes, with evidence of myelin sheath production at the site of SCI. ${ }^{20,46}$ Human ESC-derived OPCs release neurotrophic factors, including neurite growth-promoting factor 2 (NEGF2) and hepatocyte growth factor (HGF), among others, which promote neurite regeneration and extension. ${ }^{9,60}$ The downside to hESC-derived cells is that, as non-autologous cells, they are prone to immunological rejection. ${ }^{51}$

For this reason, among others, induced pluripotent stem cells (iPSCs) have gained traction in the field in recent years. Created through viral transduction of SOX2, OCT3/4, KLF4, and c-MYC in somatic cells, ${ }^{50}$ these cells are an attractive alternative to hESCs. Because they can differentiate into neurons, oligodendrocytes, and astrocytes, they avoid the ethical considerations of hESCs. ${ }^{56}$ As autologous cells, they are less prone to immunological rejection. ${ }^{15,59}$ Autologous iPSC-derived neural precursor cells (iPSC-NPCs) can be efficiently produced and transplanted into SCI models. ${ }^{46}$ Further, they are able to differentiate into myelin-producing oligodendrocytes and migrate within the spinal cord to promote functional connections and recovery. ${ }^{11}$

\section{Preclinical Studies Evaluating Immunotherapeutic Adjuvants to Stem Cell Transplantation}

The efficacy of these grafts appears to be limited by the inhibitory mechanisms outlined above. There is considerable interest in developing immunological therapeutics to target these mechanisms. Specifically, tacrolimus and cyclosporine have emerged as promising potential adjuvants, enhancing graft survival and recovery following SCI.

\section{Tacrolimus}

Tacrolimus (also known as FK506) is an immunosuppressive drug of choice that is often administered as a monotherapy or in a multi-drug regimen along with other immunosuppressants with different mechanisms of action..$^{16}$ The mechanism by which tacrolimus induces immunosuppression is primarily through inhibition of Tlymphocyte proliferation. Tacrolimus binds the FK506 binding protein (FKBP), thus inhibiting the peptidyl-prolyl cis-trans isomerase activity of FKBP. Though the exact function of FKBP, an immunophilin, is not clear with respect to T-lymphocyte activation, ${ }^{35}$ formation of a pentameric complex between tacrolimus, FKBP, calcineurin $\mathrm{A}$, calcineurin $\mathrm{B}$, and calmodulin is known to inhibit the phosphatase activity of calcineurin. ${ }^{48}$ Dephosphorylation of the family of NFAT transcription factors by calcineurin normally allows NFAT translocation into the nucleus, where it increases transcription of genes required for T-cell activation and proliferation. Tacrolimus is commercialized in more than 70 countries and is currently the drug of choice for immunosuppression following transplantation procedures, including heart, kidney, liver, and bone marrow transplants. ${ }^{31}$ Vicari-Christensen et al. demonstrated 
TABLE 1. Summary of preclinical studies examining stem cell transplantation with adjuvant tacrolimus

\begin{tabular}{|c|c|c|c|c|c|c|c|}
\hline $\begin{array}{l}\text { Authors \& } \\
\text { Year }\end{array}$ & $\begin{array}{l}\text { Study } \\
\text { Type }\end{array}$ & Model/Subjects & Injury & $\begin{array}{l}\text { Transplant Cell } \\
\text { Type }\end{array}$ & Immunosuppressant Regimen & Graft Survival & $\begin{array}{l}\text { Motor Function } \\
\text { Recovery }\end{array}$ \\
\hline $\begin{array}{l}\text { Sevc et al., } \\
2013\end{array}$ & Animal & SD rats & $\begin{array}{l}\text { L3 contu- } \\
\text { sion }\end{array}$ & HUES7-NPCs & $\begin{array}{l}\text { Tacrolimus + MMF (SC): 1st } 14 \\
\text { days following transplant; } \\
\text { tacrolimus (SC): after day 14, } \\
\text { varying doses }\end{array}$ & $\begin{array}{l}\text { Yes, sig impr w/ } \\
\text { immunosup- } \\
\text { pression }\end{array}$ & NR \\
\hline $\begin{array}{l}\text { Torres- } \\
\text { Espín et } \\
\text { al., } 2015\end{array}$ & Animal & SD rats & $\begin{array}{l}\text { T8-9 contu- } \\
\text { sion }\end{array}$ & MSCs & $\begin{array}{l}\text { Tacrolimus (IP): } 2 \mathrm{mg} / \mathrm{kg} \text { bolus im- } \\
\text { mediately following inj }+1 \mathrm{mg} / \\
\text { kg daily until end of FU }\end{array}$ & $\begin{array}{l}\text { Yes, sig impr w/ } \\
\text { immunosup- } \\
\text { pression }\end{array}$ & $\begin{array}{l}\text { Slight impr w/ im- } \\
\text { munosuppres- } \\
\text { sion (not sig) }\end{array}$ \\
\hline $\begin{array}{l}\text { Pomeshchik } \\
\text { et al., } \\
2015\end{array}$ & Animal & C57BL/6 mice & $\begin{array}{l}\text { T10 contu- } \\
\text { sion }\end{array}$ & hiPSC-NPCs & $\begin{array}{l}\text { Tacrolimus (IP): daily } 2 \mathrm{mg} / \mathrm{kg} \\
\text { bolus }\end{array}$ & $\begin{array}{l}\text { Poor long-term } \\
\text { survival }\end{array}$ & $\begin{array}{l}\text { No impr w/ stem } \\
\text { cell inj (com- } \\
\text { pared to control) }\end{array}$ \\
\hline $\begin{array}{l}\text { Iwai et al., } \\
2015\end{array}$ & Animal & $\begin{array}{l}\text { Adult female } \\
\text { common } \\
\text { marmosets }\end{array}$ & $\begin{array}{l}\text { C5 contu- } \\
\text { sion }\end{array}$ & $\begin{array}{l}\text { ESC-derived } \\
\text { NS/PCs }\end{array}$ & Tacrolimus (SC): $1 \mathrm{mg} / \mathrm{kg} /$ day & Yes & $\begin{array}{l}\text { Impr w/ stem cell } \\
\text { inj (compared to } \\
\text { control) }\end{array}$ \\
\hline $\begin{array}{l}\text { Itakura et } \\
\quad \text { al., } 2015\end{array}$ & Animal & $\begin{array}{l}\text { C57BL/6 H-2kb } \\
\text { mice }\end{array}$ & None & $\begin{array}{l}\text { Human GBM cell } \\
\text { line U251 MG }\end{array}$ & Tacrolimus (SC): 5 mg/kg/day & $\begin{array}{l}\text { Yes, sig impr w/ } \\
\text { immunosup- } \\
\text { pression }\end{array}$ & NR \\
\hline $\begin{array}{l}\text { van Gorp et } \\
\text { al., } 2013\end{array}$ & Animal & SD rats & $\begin{array}{l}\text { L3 com- } \\
\text { pression }\end{array}$ & hSSCs & $\begin{array}{l}\text { Tacrolimus (SC): } 1.5 \mathrm{mg} / \mathrm{kg} \text { BID; } \\
\text { MMF (SC): } 30 \mathrm{mg} / \mathrm{kg} / \mathrm{day} \text { for } \\
\text { days 0-10; methylprednisolone } \\
\text { acetate (IM): varied dosing }\end{array}$ & Yes & Yes \\
\hline $\begin{array}{l}\text { Itakura et } \\
\quad \text { al., } 2015\end{array}$ & Animal & $\begin{array}{l}\text { C57BL/6 H-2kb } \\
\text { mice }\end{array}$ & None & $\begin{array}{l}\text { Human GBM cell } \\
\text { line U251 MG }\end{array}$ & $\begin{array}{l}\text { Tacrolimus (SC): } 5 \mathrm{mg} / \mathrm{kg} / \text { day; anti- } \\
\text { CD4 mAb (SC): } 10 \mathrm{mg} / \mathrm{kg} / \text { day }\end{array}$ & $\begin{array}{c}\text { Sig impr w/ immu- } \\
\text { nosuppression }\end{array}$ & NR \\
\hline $\begin{array}{l}\text { Li et al., } \\
2015\end{array}$ & Animal & $\begin{array}{l}\text { C57BL/6 WT } \\
\text { mice }\end{array}$ & $\begin{array}{l}\text { C4 contu- } \\
\text { sion }\end{array}$ & $\begin{array}{l}\text { hiPSC-derived } \\
\text { astroyctes }\end{array}$ & $\begin{array}{l}\text { Tacrolimus (SC): } 1 \mathrm{mg} / \mathrm{kg} / \mathrm{day} ; \\
\text { rapamycin (SC): } 1 \mathrm{mg} / \mathrm{kg} / \text { day }\end{array}$ & Yes & NR \\
\hline $\begin{array}{l}\text { Rosenzweig } \\
\text { et al., } \\
2018\end{array}$ & Animal & $\begin{array}{l}\text { Adult male rhe- } \\
\text { sus monkeys }\end{array}$ & $\begin{array}{l}\text { Rt C7 hemi- } \\
\text { section }\end{array}$ & $\begin{array}{l}\text { Human spinal } \\
\text { cord-derived } \\
\text { NPCs }\end{array}$ & $\begin{array}{l}\text { Tacrolimus: varying doses + MMF: } \\
\text { varying doses }\end{array}$ & $\begin{array}{l}\text { Yes, impr w/ in- } \\
\text { creased doses } \\
\text { of immunosup- } \\
\text { pression }\end{array}$ & $\begin{array}{l}\text { Yes, impr w/ } \\
\text { increased doses } \\
\text { of immunosup- } \\
\text { pression }\end{array}$ \\
\hline
\end{tabular}

BID = twice daily; FU = follow-up; GBM = glioblastoma multiforme; hiPSC-NPCs = human iPSC-NPCs; IM = intramuscular; impr = improvement; inj = injection; IP = intraperitoneal; $\mathrm{mAb}=$ monoclonal antibody; MMF = mycophenolate mofetil; NR = not reported; NS/PCs = neural stem/progenitor cells; $\mathrm{SC}=$ subcutaneous; $\mathrm{SD}=$ Sprague-Dawley; sig = significant; WT = wild-type.

that tacrolimus prolongs survival in patients receiving solid organ transplants, and critically, exhibits tolerable adverse effects. ${ }^{54}$ Numerous studies over the past decade have attempted to apply the immunosuppressive qualities of tacrolimus to prevent the rejection of allogeneic stem cell transplantation into spinal cord lesions (Table 1).

In 2013, Sevc et al. demonstrated the safety and efficacy of subcutaneously delivered tacrolimus formulations in promoting graft survival following SCI in a rat model. ${ }^{48}$ Sevc et al. demonstrated that a dose of $4.9 \mathrm{mg} / \mathrm{kg} /$ day of tacrolimus, administered through a subcutaneous pellet, allowed for graft survival in L3 spinal contusion models. The spinal graft was characterized by advanced neuronal maturation, neurons that had migrated outside of the grafts, and only the occasional presence of lymphocytic infiltration. In an effort to confirm the role of immunosuppression in the success of the graft, human fetal spinal cord stem cells (hSSCs) were then grafted in the absence of immunosuppression. The resultant spinal cord showed complete graft rejection with significant lymphocytic infiltration. Itakura et al. corroborated these findings by showing that immunosuppression with tacrolimus monotherapy significantly improved xenograft survival in mice. ${ }^{18}$ At 28 days post-transplant, the graft survival rate was $82 \%$ in mice treated with daily subcutaneous injections of $5 \mathrm{mg} / \mathrm{kg}$ tacrolimus. This was compared to a $0 \%$ graft survival rate at 28 days for immunocompetent mice without immunosuppression.

Similarly, Torres-Espín et al. showed that intraperitoneal administration of tacrolimus following the engraftment of mesenchymal stem cells at the site of SCI was associated with improved graft survival..$^{52}$ Mesenchymal stem cells (MSCs) have been shown to modulate the host inflammatory response, increase tissue sparing, and support axonal recovery. ${ }^{52}$ Nevertheless, MSC grafts in immunocompetent hosts have exhibited only marginal recovery of motor and sensory function following SCI. In models that received both high-dose and low-dose MSC grafts following T8-9 spinal contusion injury, immunosuppression through intraperitoneal tacrolimus significantly improved late graft survival at 21 and 42 days postprocedure. In contrast, the functional recovery was only slightly improved in the presence of tacrolimus immunosuppression, with no significance demonstrated between immunosuppressed and non-immunosuppressed groups. Injection of human iPSC-NPCs into C57BL/6 mice with moderately 
contused SCI has also failed to improve locomotor testing in the presence of intraperitoneal tacrolimus immunosuppression. ${ }^{42}$ However, in this case there was also poor graft survival, which is a likely explanation for the absence in functional recovery.

Other studies have successfully been able to demonstrate improved graft survival in conjunction with functional recovery following SCI. Iwai et al. showed that embryonic stem cell-derived neural stem/progenitor cells grafted into C5 contused adult female common marmosets exhibited significant improvement in motor function of upper extremities as well as open-field locomotion. ${ }^{19}$ In the presence of tacrolimus immunosuppression, stem cell grafting showed significant improvement in open-field testing 4 weeks post-transplant, and significant improvement on grip strength test 9 weeks post-transplant. This recovery in motor function was accompanied by immunohistochemical confirmation of graft cell survival that migrated extensively into both gray and white matter at the lesion epicenter.

The enhancement of immunosuppression through the use of multiple drug therapies with different targets may allow for improved graft survival. Itakura et al. demonstrated a $100 \%$ graft survival rate at 28 days following intraspinal stem cell transplantation of mice immunosuppressed with a combination of tacrolimus and anti-CD4 monoclonal antibody. ${ }^{18}$ As mentioned above, only an $82 \%$ graft survival rate was achieved in mice immunosuppressed with tacrolimus alone. Along similar lines, Li et al. was successful in demonstrating robust graft survival in human iPSC-derived astrocyte engraftment in the presence of tacrolimus and rapamycin, an mTOR inhibitor. ${ }^{26}$ In 2013, van Gorp et al. used the combination of tacrolimus, mycophenolate mofetil, and methylprednisolone as immunosuppressive therapy following hSSC transplantation into L3 compression injury in Sprague-Dawley rats. ${ }^{53} \mathrm{Im}-$ munofluorescence analysis and MRI volume reconstruction depicted near-complete filling of the injury cavity as well as the formation of putative GABA-ergic synapses between host and grafted neurons. Additionally, significant recovery of motor and sensory function was exhibited in these rats. A similar immunosuppressive therapy has proven successful in nonhuman primates. ${ }^{45}$ The dosage of mycophenolate mofetil, an inosine monophosphate (IMP) dehydrogenase inhibitor, and tacrolimus following injection of neural progenitor cells into the $\mathrm{C} 7$ hemisection lesion site of marmosets seemed to influence the outcomes of the procedure. At low doses, no or minimal graft survival was demonstrated 2 months postoperatively. Escalation of the dosage of both mycophenolate mofetil and tacrolimus in addition to increased monitoring of serum immunosuppressant drug levels exhibited robust graft survival and filling of the lesion site.

\section{Cyclosporine}

Cyclosporine (also known as cyclosporine A or CsA), another potential immunosuppressant commonly employed to prevent allograft rejection and graft versus host disease, functions to inhibit T-cell activation. ${ }^{32}$ Similar to the mechanism of tacrolimus, cyclosporine inhibits the transcription of IL-2 by activated T cells through inhibi- tion of calcineurin-mediated dephosphorylation of NFAT. Cyclosporine binds cyclophilins with high affinity, and this cyclophilin-cyclosporine is able to associate with calcineurin to prevent its activity. Cyclosporine has been utilized in numerous studies as a possible mechanism of immunosuppression to prevent rejection of stem cell allograft procedures following SCI (Table 2).

In 2013, Nutt et al. reported the use of daily subcutaneous cyclosporine injections following transplantation of human induced pluripotent stem cells (hiPSCs) in the C4 contusion injury rat model. ${ }^{37}$ Immunofluorescence indicated significant survival and differentiation of grafted stem cells at 8 weeks post-transplant. This result, however, lacked an association with functional recovery. Assessment of the forelimb reaching task and the limb-use asymmetry test demonstrated no significant improvement. In contrast, Oh et al. achieved increased graft survival and improved functional recovery following intraspinal discderived iPSC graft into T11 compression injury mice in the presence of daily cyclosporine immunosuppression. ${ }^{38}$ The variation in functional recovery outcomes among the two studies is likely due to the difference in stem cells grafted and animal models used. Similar to their results with tacrolimus immunosuppression, Li et al. also demonstrated robust graft survival of human iPSC-derived astrocytes in a $\mathrm{C} 4$ contusion model. ${ }^{27}$

Despite some success of graft survival in stem cell transplantation with cyclosporine-mediated immunosuppression, other studies have demonstrated a weak or absent effect of cyclosporine immunosuppression on stem cell graft survival. Sparling et al. transplanted skin-derived precursor Schwann cells (SKP-SCs) into a C4-5 DLF lesion rat model. ${ }^{49}$ Comparison of the cyclosporine-immunosuppressed and non-immunosuppressed groups showed no significant difference on parameters including limb motor function, forelimb EMG, and immunohistochemical analysis of graft survival. These results may indicate that the immune response against the grafted SKP-SCs was not T cell mediated, and thus cyclosporine was not protective for the graft. Another study that showed no effect of cyclosporine immunosuppression in the grafting of SKP-SCs into a T8 hemisection rat model supports the hypothesis that a T-cell-mediated immune response may not be involved. ${ }^{33}$

In addition to the lack of effect by cyclosporine administration, transplantation of the SKP-SCs into rats of a different substrain than the donor yielded similar graft survival as the substrain matched models. This finding further corroborates the theory that immunosuppression, specifically by cyclosporine, would not be beneficial in SKP-SC transplantation. Hodgetts et al. also demonstrated a null effect of cyclosporine-mediated immunosuppression on the success of mesenchymal precursor cell injection into T9-10 athymic nude rats. ${ }^{17} \mathrm{~A}$ logical explanation for the absence of effect in this case is that the athymic nude rats were already $\mathrm{T}$ cell deficient, and thus their immune response against the graft was mediated by mechanisms not affected by cyclosporine activity.

Human iPSC engraftment into a T8-9 compression injury rat model in the presence of cyclosporine, azathioprine sodium, and methylprednisolone has demonstrated success. ${ }^{44}$ Human iPSCs exhibited robust survival in the 
TABLE 2. Summary of preclinical studies examining stem cell transplantation with adjuvant cyclosporine

\begin{tabular}{|c|c|c|c|c|c|c|c|}
\hline $\begin{array}{l}\text { Authors \& } \\
\quad \text { Year }\end{array}$ & $\begin{array}{l}\text { Study } \\
\text { Type }\end{array}$ & Model/Subjects & Injury & $\begin{array}{l}\text { Transplant Cell } \\
\text { Type }\end{array}$ & $\begin{array}{l}\text { Immunosuppressant } \\
\text { Regimen }\end{array}$ & Graft Survival & $\begin{array}{l}\text { Motor Function } \\
\text { Recovery }\end{array}$ \\
\hline $\begin{array}{l}\text { Nutt et al., } \\
2013\end{array}$ & Animal & $\begin{array}{l}\text { Adult female } \\
\text { Long-Evan } \\
\text { rats }\end{array}$ & $\begin{array}{l}\text { C4 contu- } \\
\text { sion }\end{array}$ & hiPSCs & $\begin{array}{l}\text { Cyclosporine (SC): } 10 \text { mg/ } \\
\text { kg/day }\end{array}$ & Yes & $\begin{array}{l}\text { No impr w/ stem cell } \\
\text { inj (compared to } \\
\text { control) }\end{array}$ \\
\hline $\begin{array}{l}\text { Hodgetts } \\
\text { et al., } \\
2013\end{array}$ & Animal & $\begin{array}{l}\text { Adult female } \\
\text { CBH-rnu/Arc } \\
\text { rats }\end{array}$ & $\begin{array}{l}\text { T9-10 } \\
\text { contu- } \\
\text { sion }\end{array}$ & hMPCs & Cyclosporine: 20 mg/kg/day & $\begin{array}{l}\text { No diff btwn immuno- } \\
\text { suppressed \& non- } \\
\text { immunosuppressed }\end{array}$ & $\begin{array}{l}\text { No diff btwn immuno- } \\
\text { suppressed \& non- } \\
\text { immunosuppressed }\end{array}$ \\
\hline $\begin{array}{l}\text { Li et al., } \\
2015\end{array}$ & Animal & Female SD rats & $\begin{array}{l}\text { C4 contu- } \\
\text { sion }\end{array}$ & $\begin{array}{l}\text { Human iPSC-de- } \\
\text { rived astrocytes }\end{array}$ & $\begin{array}{l}\text { Cyclosporine (SC): } 10 \text { mg/ } \\
\text { kg/day }\end{array}$ & Yes & NA \\
\hline $\begin{array}{l}\text { Oh et al., } \\
2015\end{array}$ & Animal & $\begin{array}{l}\text { Adult male ICR } \\
\text { mice }\end{array}$ & $\begin{array}{l}\text { T11 com- } \\
\text { pression }\end{array}$ & $\begin{array}{l}\text { Disc-derived } \\
\text { iPSCs }\end{array}$ & Cyclosporine: 10 mg/kg/day & Yes & Yes \\
\hline $\begin{array}{l}\text { Sparling } \\
\text { et al., } \\
2015\end{array}$ & Animal & SD rats & $\begin{array}{l}\text { C4-5 DLF } \\
\text { lesion }\end{array}$ & SKP-SCs & $\begin{array}{l}\text { Cyclosporine (IP): } 10 \text { mg/kg/ } \\
\text { day for } 2 \text { wks post-trans- } \\
\text { plant; cyclosporine (PO): } \\
\text { after } 2 \text { wks post-transplant }\end{array}$ & $\begin{array}{l}\text { No diff btwn immuno- } \\
\text { suppressed \& non- } \\
\text { immunosuppressed }\end{array}$ & $\begin{array}{l}\text { No diff btwn immuno- } \\
\text { suppressed \& non- } \\
\text { immunosuppressed }\end{array}$ \\
\hline $\begin{array}{l}\text { May et al., } \\
2017\end{array}$ & Animal & $\begin{array}{l}\text { Female Fischer } \\
\text { rats, sub- } \\
\text { strain CDF }\end{array}$ & $\begin{array}{l}\text { Rt T8 } \\
\text { hemi- } \\
\text { section }\end{array}$ & SKP-SCS & $\begin{array}{l}\text { Cyclosporine (SC): } 15 \text { mg/ } \\
\text { kg/day }\end{array}$ & $\begin{array}{l}\text { No diff btwn immuno- } \\
\text { suppressed \& non- } \\
\text { immunosuppressed }\end{array}$ & $\begin{array}{l}\text { No diff btwn immuno- } \\
\text { suppressed \& non- } \\
\text { immunosuppressed }\end{array}$ \\
\hline $\begin{array}{l}\text { Romanyuk } \\
\text { et al., } \\
2015\end{array}$ & Animal & $\begin{array}{l}\text { Male Wistar } \\
\text { rats }\end{array}$ & $\begin{array}{l}\text { T8-9 com- } \\
\text { pression }\end{array}$ & hiPSCs & $\begin{array}{l}\text { Cyclosporine: } 10 \text { mg/kg/day; } \\
\text { azathioprine sodium: } 2 \\
\text { mg/kg/day; methylpred- } \\
\text { nisolone: } 2 \text { mg/kg/day }\end{array}$ & Yes & Yes \\
\hline
\end{tabular}

Diff $=$ difference; hMPCs $=$ human mesenchymal precursor cells; $\mathrm{PO}=$ by mouth.

lesion and migrated to and partially filled the lesion cavity. Moreover, significant motor improvement was observed within 2 weeks of the transplantation procedure. In contrast, as mentioned above, iPSC grafts into C4 contusion injury rat models in the presence of cyclosporine monotherapy displayed graft survival without improvement in functional recovery. ${ }^{37}$ The location of the injury is a possible explanation for the difference in regeneration of motor function, though the addition of azathioprine, an immunosuppressant shown to improve renal allograft survival, and a glucocorticoid to the cyclosporine regimen may have influenced the results as well. ${ }^{30}$

\section{Clinical Applications of Immunotherapeutic Adjuvants to Stem Cell Transplantation}

Several clinical trials have been performed to assess the safety of stem cell engraftment in patients with SCI. Geffner et al. and Mendonca et al., in their respective phase I studies, demonstrated that transplantation of autologous stem cells is safe and feasible, with potential for neurological improvement. ${ }^{12,34}$ Ongoing phase I/II clinical trials continue to further assess stem cell transplantation (NCT02326662, NCT03505034, and NCT02687672).

While these trials examine stem cell transplantation alone for SCI, there have been a limited number of studies further investigating the combination of transplantation with adjuvant immune therapies (Table 3 ).

The combination therapy of basiliximab (an anti-IL-2 receptor monoclonal antibody), mycophenolate mofetil, and tacrolimus has previously been used successfully in a phase I trial for intraspinal transplantation of stem cells in amyotrophic lateral sclerosis (ALS) patients..$^{13}$ Curtis et al. used this combination therapy in a phase I study for

TABLE 3. Clinical applications: summary of clinical trials examining stem cell transplantation with adjuvant treatments

\begin{tabular}{|c|c|c|c|c|c|c|c|}
\hline $\begin{array}{l}\text { Authors } \\
\& \text { Year }\end{array}$ & $\begin{array}{l}\text { Study } \\
\text { Type }\end{array}$ & $\begin{array}{l}\text { Model/ } \\
\text { Subjects }\end{array}$ & Injury & Transplant Cell Type & Immunosuppressant Regimen & $\begin{array}{l}\text { Graft } \\
\text { Survival }\end{array}$ & $\begin{array}{c}\text { Motor Function } \\
\text { Recovery }\end{array}$ \\
\hline $\begin{array}{l}\text { Curtis } \\
\text { et al., } \\
2018\end{array}$ & $\begin{array}{l}\text { Phase I } \\
\text { study }\end{array}$ & $\begin{array}{l}\text { Pts w/ } \\
\text { T2-12 } \\
\text { SCl }\end{array}$ & $\begin{array}{r}\mathrm{T} 2-12 \\
\mathrm{SCl}\end{array}$ & $\begin{array}{l}\text { Human spinal cord- } \\
\text { derived neural stem } \\
\text { cells (NSI-566) }\end{array}$ & $\begin{array}{l}\text { Basiliximab (IV): } 20 \mathrm{mg} \text { during transplant \& POD 4; ta- } \\
\text { crolimus (PO): BID to maintain level of } 4-8 \mathrm{ng} / \mathrm{mL} ; \\
\text { MMF (PO): dose escalation starting at } 500 \mathrm{mg} \mathrm{BID}\end{array}$ & NR & $\begin{array}{l}\text { Yes (no statis- } \\
\text { tical power) }\end{array}$ \\
\hline $\begin{array}{l}\text { Levi et } \\
\quad \text { al., } \\
2018\end{array}$ & $\begin{array}{l}\text { Phase II } \\
\text { single- } \\
\text { blind } \\
\text { RCT }\end{array}$ & $\begin{array}{l}\text { Pts w/ } \\
\text { chronic } \\
\text { C5-7 tet- } \\
\text { raplegia }\end{array}$ & $\begin{array}{l}\text { C5-7 } \\
\text { in- } \\
\text { jury }\end{array}$ & $\begin{array}{l}\text { Human CNS stem } \\
\text { cells }\end{array}$ & $\begin{array}{l}\text { Tacrolimus (PO): monitored blood levels }(5-10 \mu \mathrm{g} / \mathrm{L} \\
\text { for } 1 \mathrm{st} 28 \text { days, } 2-5 \mu \mathrm{g} / \mathrm{L} \text { for following } 5 \text { mos); TMP: } \\
6 \text { mos; MMF: } 1 \text { mo; dexamethasone + pantopra- } \\
\text { zole: day before + } 7 \text { days after transplantation }\end{array}$ & NR & Yes \\
\hline
\end{tabular}

$\mathrm{POD}=$ postoperative day; pts = patients; RCT = randomized controlled trial; $\mathrm{TMP}$ = trimethoprim-sulfamethoxazole. 
the transplantation of human spinal cord-derived neural stem cells into four subjects with T2-12 SCI. ${ }^{4}$ At $18-27$ months postcell delivery, no significant adverse effects were noted. Subjects showed functional change, including new voluntary muscle activity at or below the level of the lesion, robust EMG changes exhibiting previously unrecorded muscle activity, and potential improvement from status of "complete" to "incomplete" SCI. Nevertheless, as a phase I study that successfully demonstrated the safety of the procedure and subsequent immunosuppression, the functional improvements lacked statistical power and require further investigation.

In a phase II single-blind randomized controlled trial, Levi et al. tested the efficacy of human neural stem cell transplantation into the cervical spinal cord of patients with chronic C5-7 tetraplegia. ${ }^{25}$ Immunosuppression was achieved through a therapeutic combination of tacrolimus, trimethoprim-sulfamethoxazole, and mycophenolate mofetil. In addition to demonstrating safety at all stem cell doses administered, the study reported improved upper extremity motor scores compared to controls.

\section{Conclusions}

Considerable resources have been poured into the development of novel strategies for SCI therapy-improvement in surgical strategies, refinement of corticosteroid regimens, and more recently, stem cell graft treatment. However, the same immunological factors that produce the glial scar and limit functional recovery also inhibit stem cell differentiation, migration, and growth at the site of injury. Studies have demonstrated the utility of immunosuppressive therapies to limit these factors and promote stem cell graft survival and maintenance. These therapies are promising and they demonstrate the potential for development of a standard clinical application for patients with SCI.

\section{References}

1. Barnabé-Heider F, Göritz C, Sabelström H, Takebayashi H, Pfrieger FW, Meletis K, et al: Origin of new glial cells in intact and injured adult spinal cord. Cell Stem Cell 7:470-482, 2010

2. Bartus K, James ND, Didangelos A, Bosch KD, Verhaagen J, Yáñez-Muñoz RJ, et al: Large-scale chondroitin sulfate proteoglycan digestion with chondroitinase gene therapy leads to reduced pathology and modulates macrophage phenotype following spinal cord contusion injury. J Neurosci 34:48224836, 2014

3. Cloutier F, Siegenthaler MM, Nistor G, Keirstead HS: Transplantation of human embryonic stem cell-derived oligodendrocyte progenitors into rat spinal cord injuries does not cause harm. Regen Med 1:469-479, 2006

4. Curtis E, Martin JR, Gabel B, Sidhu N, Rzesiewicz TK, Mandeville R, et al: A first-in-human, phase I study of neural stem cell transplantation for chronic spinal cord injury. Cell Stem Cell 22:941-950.e6, 2018

5. David S, Aguayo AJ: Axonal elongation into peripheral nervous system "bridges" after central nervous system injury in adult rats. Science 214:931-933, 1981

6. Donnelly DJ, Popovich PG: Inflammation and its role in neuroprotection, axonal regeneration and functional recovery after spinal cord injury. Exp Neurol 209:378-388, 2008

7. Duan H, Song W, Zhao W, Gao Y, Yang Z, Li X: Endogenous neurogenesis in adult mammals after spinal cord injury. Sci China Life Sci 59:1313-1318, 2016

8. Edgerton VR, Harkema S: Epidural stimulation of the spinal cord in spinal cord injury: current status and future challenges. Expert Rev Neurother 11:1351-1353, 2011

9. Faulkner J, Keirstead HS: Human embryonic stem cell-derived oligodendrocyte progenitors for the treatment of spinal cord injury. Transpl Immunol 15:131-142, 2005

10. Fawcett JW: Overcoming inhibition in the damaged spinal cord. J Neurotrauma 23:371-383, 2006

11. Fujimoto Y, Abematsu M, Falk A, Tsujimura K, Sanosaka T, Juliandi B, et al: Treatment of a mouse model of spinal cord injury by transplantation of human induced pluripotent stem cell-derived long-term self-renewing neuroepithelial-like stem cells. Stem Cells 30:1163-1173, 2012

12. Geffner LF, Santacruz P, Izurieta M, Flor L, Maldonado B, Auad AH, et al: Administration of autologous bone marrow stem cells into spinal cord injury patients via multiple routes is safe and improves their quality of life: comprehensive case studies. Cell Transplant 17:1277-1293, 2008

13. Glass JD, Boulis NM, Johe K, Rutkove SB, Federici T, Polak $M$, et al: Lumbar intraspinal injection of neural stem cells in patients with amyotrophic lateral sclerosis: results of a phase I trial in 12 patients. Stem Cells 30:1144-1151, 2012

14. Haan N, Zhu B, Wang J, Wei X, Song B: Crosstalk between macrophages and astrocytes affects proliferation, reactive phenotype and inflammatory response, suggesting a role during reactive gliosis following spinal cord injury. J Neuroinflammation 12:109, 2015

15. Hallett PJ, Deleidi M, Astradsson A, Smith GA, Cooper O, Osborn TM, et al: Successful function of autologous iPSCderived dopamine neurons following transplantation in a non-human primate model of Parkinson's disease. Cell Stem Cell 16:269-274, 2015

16. Hefferan MP, Johe K, Hazel T, Feldman EL, Lunn JS, Marsala M: Optimization of immunosuppressive therapy for spinal grafting of human spinal stem cells in a rat model of ALS. Cell Transplant 20:1153-1161, 2011

17. Hodgetts SI, Simmons PJ, Plant GW: Human mesenchymal precursor cells $\left(\right.$ Stro- $\left.1^{+}\right)$from spinal cord injury patients improve functional recovery and tissue sparing in an acute spinal cord injury rat model. Cell Transplant 22:393-412, 2013

18. Itakura G, Kobayashi Y, Nishimura S, Iwai H, Takano M, Iwanami A, et al: Control of the survival and growth of human glioblastoma grafted into the spinal cord of mice by taking advantage of immunorejection. Cell Transplant 24:1299-1311, 2015

19. Iwai H, Shimada H, Nishimura S, Kobayashi Y, Itakura G, Hori K, et al: Allogeneic neural stem/progenitor cells derived from embryonic stem cells promote functional recovery after transplantation into injured spinal cord of nonhuman primates. Stem Cells Transl Med 4:708-719, 2015

20. Keirstead HS, Nistor G, Bernal G, Totoiu M, Cloutier F, Sharp K, et al: Human embryonic stem cell-derived oligodendrocyte progenitor cell transplants remyelinate and restore locomotion after spinal cord injury. J Neurosci 25:4694-4705, 2005

21. Khalatbary AR, Tiraihi T, Boroujeni MB, Ahmadvand H, Tavafi M, Tamjidipoor A: Effects of epigallocatechin gallate on tissue protection and functional recovery after contusive spinal cord injury in rats. Brain Res 1306:168-175, 2010

22. Khurana SR, Garg DS: Spasticity and the use of intrathecal baclofen in patients with spinal cord injury. Phys Med Rehabil Clin N Am 25:655-669, ix, 2014

23. Kigerl KA, McGaughy VM, Popovich PG: Comparative analysis of lesion development and intraspinal inflammation in four strains of mice following spinal contusion injury. $\mathbf{J}$ Comp Neurol 494:578-594, 2006

24. Kubota K, Saiwai H, Kumamaru H, Maeda T, Ohkawa Y, 
Aratani Y, et al: Myeloperoxidase exacerbates secondary injury by generating highly reactive oxygen species and mediating neutrophil recruitment in experimental spinal cord injury. Spine (Phila Pa 1976) 37:1363-1369, 2012

25. Levi AD, Anderson KD, Okonkwo DO, Park P, Bryce TN, Kurpad SN, et al: Clinical outcomes from a multi-center study of human neural stem cell transplantation in chronic cervical spinal cord injury. $\mathbf{J}$ Neurotrauma [epub ahead of print], 2018

26. Li J, Kim SG, Blenis J: Rapamycin: one drug, many effects. Cell Metab 19:373-379, 2014

27. Li K, Javed E, Scura D, Hala TJ, Seetharam S, Falnikar A, et al: Human iPS cell-derived astrocyte transplants preserve respiratory function after spinal cord injury. Exp Neurol 271:479-492, 2015

28. Luchetti S, Beck KD, Galvan MD, Silva R, Cummings BJ, Anderson AJ: Comparison of immunopathology and locomotor recovery in C57BL/6, BUB/BnJ, and NOD-SCID mice after contusion spinal cord injury. J Neurotrauma 27:411-421, 2010

29. Lukovic D, Moreno Manzano V, Stojkovic M, Bhattacharya SS, Erceg S: Concise review: human pluripotent stem cells in the treatment of spinal cord injury. Stem Cells 30:1787-1792, 2012

30. Maltzman JS, Koretzky GA: Azathioprine: old drug, new actions. J Clin Invest 111:1122-1124, 2003

31. Masson MAC, Karpfenstein R, de Oliveira-Silva D, Teuler JM, Archirel P, Maître P, et al: Evaluation of $\mathrm{Ca}^{2+}$ binding sites in tacrolimus by infrared multiple photon dissociation spectroscopy. J Phys Chem B 122:9860-9868, 2018

32. Matsuda S, Koyasu SJI: Mechanisms of action of cyclosporine. Immunopharmacology 47:119-125, 2000

33. May Z, Torres-Espín A, Lucas-Osma AM, Batty NJ, Raposo P, Fenrich KK, et al: Cyclosporine-immunosuppression does not affect survival of transplanted skin-derived precursor Schwann cells in the injured rat spinal cord. Neurosci Lett 658:67-72, 2017

34. Mendonça MV, Larocca TF, de Freitas Souza BS, Villarreal CF, Silva LF, Matos AC, et al: Safety and neurological assessments after autologous transplantation of bone marrow mesenchymal stem cells in subjects with chronic spinal cord injury. Stem Cell Res Ther 5:126, 2014

35. Moore JM, Peattie DA, Fitzgibbon MJ, Thomson JA: Solution structure of the major binding protein for the immunosuppressant FK506. Nature 351:248-250, 1991

36. Mostacada K, Oliveira FL, Villa-Verde DM, Martinez AM: Lack of galectin-3 improves the functional outcome and tissue sparing by modulating inflammatory response after a compressive spinal cord injury. Exp Neurol 271:390-400, 2015

37. Nutt SE, Chang EA, Suhr ST, Schlosser LO, Mondello SE, Moritz CT, et al: Caudalized human iPSC-derived neural progenitor cells produce neurons and glia but fail to restore function in an early chronic spinal cord injury model. Exp Neurol 248:491-503, 2013

38. Oh J, Lee KI, Kim HT, You Y, Yoon DH, Song KY, et al: Human-induced pluripotent stem cells generated from intervertebral disc cells improve neurologic functions in spinal cord injury. Stem Cell Res Ther 6:125, 2015

39. O'Shea TM, Burda JE, Sofroniew MV: Cell biology of spinal cord injury and repair. J Clin Invest 127:3259-3270, 2017

40. Oyinbo CA: Secondary injury mechanisms in traumatic spinal cord injury: a nugget of this multiply cascade. Acta Neurobiol Exp (Warsz) 71:281-299, 2011

41. Pineau I, Sun L, Bastien D, Lacroix S: Astrocytes initiate inflammation in the injured mouse spinal cord by promoting the entry of neutrophils and inflammatory monocytes in an IL-1 receptor/MyD88-dependent fashion. Brain Behav Immun 24:540-553, 2010
42. Pomeshchik Y, Puttonen KA, Kidin I, Ruponen M, Lehtonen $\mathrm{S}$, Malm T, et al: Transplanted human induced pluripotent stem cell-derived neural progenitor cells do not promote functional recovery of pharmacologically immunosuppressed mice with contusion spinal cord injury. Cell Transplant 24:1799-1812, 2015

43. Ramon y Cajal S: Degeneration \& Regeneration of the Nervous System. New York: Hafner, 1959, Vol 1

44. Romanyuk N, Amemori T, Turnovcova K, Prochazka P, Onteniente B, Sykova E, et al: Beneficial effect of human induced pluripotent stem cell-derived neural precursors in spinal cord injury repair. Cell Transplant 24:1781-1797, 2015

45. Rosenzweig ES, Brock JH, Lu P, Kumamaru H, Salegio EA, Kadoya K, et al: Restorative effects of human neural stem cell grafts on the primate spinal cord. Nat Med 24:484-490, 2018

46. Salewski RP, Mitchell RA, Shen C, Fehlings MG: Transplantation of neural stem cells clonally derived from embryonic stem cells promotes recovery after murine spinal cord injury. Stem Cells Dev 24:36-50, 2015

47. Satake K, Matsuyama Y, Kamiya M, Kawakami H, Iwata H, Adachi K, et al: Nitric oxide via macrophage iNOS induces apoptosis following traumatic spinal cord injury. Brain Res Mol Brain Res 85:114-122, 2000

48. Sevc J, Goldberg D, van Gorp S, Leerink M, Juhas S, Juhasova J, et al: Effective long-term immunosuppression in rats by subcutaneously implanted sustained-release tacrolimus pellet: effect on spinally grafted human neural precursor survival. Exp Neurol 248:85-99, 2013

49. Sparling JS, Bretzner F, Biernaskie J, Assinck P, Jiang Y, Arisato $\mathrm{H}$, et al: Schwann cells generated from neonatal skin-derived precursors or neonatal peripheral nerve improve functional recovery after acute transplantation into the partially injured cervical spinal cord of the rat. J Neurosci 35:6714-6730, 2015

50. Takahashi K, Yamanaka S: Induction of pluripotent stem cells from mouse embryonic and adult fibroblast cultures by defined factors. Cell 126:663-676, 2006

51. Tetzlaff W, Okon EB, Karimi-Abdolrezaee S, Hill CE, Sparling JS, Plemel JR, et al: A systematic review of cellular transplantation therapies for spinal cord injury. J Neurotrauma 28:1611-1682, 2011

52. Torres-Espín A, Redondo-Castro E, Hernandez J, Navarro $\mathrm{X}$ : Immunosuppression of allogenic mesenchymal stem cells transplantation after spinal cord injury improves graft survival and beneficial outcomes. J Neurotrauma 32:367-380, 2015

53. van Gorp S, Leerink M, Kakinohana O, Platoshyn O, Santucci C, Galik J, et al: Amelioration of motor/sensory dysfunction and spasticity in a rat model of acute lumbar spinal cord injury by human neural stem cell transplantation. Stem Cell Res Ther 4:57, 2013

54. Vicari-Christensen M, Repper S, Basile S, Young D: Tacrolimus: review of pharmacokinetics, pharmacodynamics, and pharmacogenetics to facilitate practitioners' understanding and offer strategies for educating patients and promoting adherence. Prog Transplant 19:277-284, 2009

55. Vidal PM, Lemmens E, Geboes L, Vangansewinkel T, Nelissen S, Hendrix S: Late blocking of peripheral TNF- $\alpha$ is ineffective after spinal cord injury in mice. Immunobiology 218:281-284, 2013

56. Volarevic V, Markovic BS, Gazdic M, Volarevic A, Jovicic $\mathrm{N}$, Arsenijevic N, et al: Ethical and safety issues of stem cellbased therapy. Int J Med Sci 15:36-45, 2018

57. Wang L, Wei FX, Cen JS, Ping SN, Li ZQ, Chen NN, et al: Early administration of tumor necrosis factor-alpha antagonist promotes survival of transplanted neural stem cells and axon myelination after spinal cord injury in rats. Brain Res 1575:87-100, 2014 
58. Watzlawick R, Kenngott EE, Liu FD, Schwab JM, Hamann A: Anti-inflammatory effects of IL-27 in zymosan-induced peritonitis: inhibition of neutrophil recruitment partially explained by impaired mobilization from bone marrow and reduced chemokine levels. PLoS One 10:e0137651, 2015

59. Zhang Y, Pak C, Han Y, Ahlenius H, Zhang Z, Chanda S, et al: Rapid single-step induction of functional neurons from human pluripotent stem cells. Neuron 78:785-798, 2013

60. Zhang YW, Denham J, Thies RS: Oligodendrocyte progenitor cells derived from human embryonic stem cells express neurotrophic factors. Stem Cells Dev 15:943-952, 2006

\section{Disclosures}

The authors report no conflict of interest concerning the materials or methods used in this study or the findings specified in this paper.

\section{Author Contributions}

Conception and design: Pham, Antonios, Farah, Cleary, Martin. Analysis and interpretation of data: Antonios, Farah. Drafting the article: Pham, Antonios, Farah. Critically revising the article: Pham, Antonios, Cleary, Ciacci. Reviewed submitted version of manuscript: Pham, Antonios, Martin, Ciacci.

\section{Correspondence}

Martin H. Pham: University of California San Diego School of Medicine, San Diego, CA. mhpham@ucsd.edu. 